\title{
Research on Club Teaching Mode Implemented in Chinese Universities
}

\author{
Yaohui Lin \\ Tan Kah Kee College \\ Xiamen University \\ Xiamen, China
}

\begin{abstract}
With the development of physical exercise and the requirement of reform in physical education in universities, traditional teaching methods have been increasingly unsuitable for the development of modern education. Club teaching of college sports rises in response to the proper time and conditions. Teaching in universities at the present stage is researched through literature review method, expert interview method and logical analysis. It reaches the conclusion that establishing clubtype scientific research team and sport training institutions in universities can effectively improve sports skills of college students and the educational and teaching quality of sports in colleges.
\end{abstract}

\section{Keywords-universities; sports club; teaching}

\section{INTRODUCTION}

At the present stage, the teaching of college sports faces great challenges because it still follows the traditional teaching models and methods, has rigid and backward teaching thoughts and fails to meet the development requirements of students in the new era. Under this condition, it urgently needs new teaching models that meet the development demands of times to meet the development requirements of universities in modern times.

\section{CONCEPTS RElated TO Club TEACHING MOdEL IN UNIVERSITIES}

Club teaching model in Chinese universities first appeared in the middle 1990s. Shenzhen University has made remarkable achievements through club teaching. Soon afterwards, universities follow the example of Shenzhen University and begin to implement the club teaching model. Therefore, many scholars research club teaching. At the same time, literature comes in a continuous stream. Scholar Liu Zhimin defines sports club in universities as the set of people in social organizations in taking sports activities spontaneously. Sports management department defines sports club as grassroots sports organization held by enterprise and public institution, social organization and citizen through nongovernmental funding to carry out sports activities. Club teaching in schools means the teaching in clubs, follows the basic law of teaching to teach, manage, organize and evaluate through club type. At present, the clubs in Chinese universities include teaching club, club jointly organized by school and society, individual sports club organized by students under school management, competitive sports club and sports club organized by individuals spontaneously. Sports club in universities reflects freedom, including the freedom of students in selection and the freedom of teachers in choosing schooltime The embodiment of freedom makes students better release emotions and learn in class. It enables teachers to follow no set form and release emotions, at the same time, greatly stimulates their enthusiasm in teaching.

\section{CHARACTERISTICS OF SPORTS CLUB IN UNIVERSITIES}

\section{A. Rich Contents}

Except for traditional events such as football, basketball and table tennis, sports clubs also provide some novel events such as rock climbing, outdoor training and roller skating. At the beginning of semester, students can select their favorite courses online to learn after term begins. Compared with the traditional class contents, club teaching in universities has richer contents for students to choose. At the same time, it better arouses the enthusiasm of students in learning and effectively improves teaching quality.

\section{B. Students Have Strong Initiative}

The appearance of sports club provides plentiful alternative events for students. These students can spontaneously select favorite ones. Selecting favorite events is the beginning of learning sports. Interest is the best teacher. With keen interest, students will make good achievements in learning sports events In traditional sports teaching, because students can only select courses passively, and there are plentiful students and the field and the facilities are limited and the class time is centralized, it discourages the enthusiasm of students in learning sports skills. In club teaching, the flexible class time and the diversified events provided arouse interests of students, so the effects of learning skills are obviously better than that of the traditional teaching methods. It makes up for the deficiencies in traditional teaching and improves learning effects and teaching quality by arousing the enthusiasm of students and teachers.

\section{Sound Management}

Compared with the traditional management system in schools, sports club has more advanced operation mechanism and clearer objectives at the meantime forms scientific standardized system with clear responsibilities of management 
organization and operation management. Sports management department gives responsibilities and power to clubs in operation and management, Besides, it regularly checks and evaluates them at the end of semester. Clubs formulate plan at the beginning of semester, in order to organize teaching according to teaching plan and summarize the teaching at the end of semester. The measures make clubs develop freely in relaxed environment. Problems in each link can be solved timely. Stages in teaching improve and develop continuously, in order to improve teaching quality ceaselessly.

\section{CONSTRUCTION AND IMPLEMENTATION OF SPORTS CLUB}

The selection of physical education class in Chinese universities bases on the interests of students, sports ground and the quantity of teachers. It is the previous preparation of club teaching reform. Based on the preparation, universities learn methods in constructing sports club and implement it through searching literature and visiting schools. These schools have implemented the club model. According to the physical truth, in the process of implementation, teaching model and management concept of sports club are established. Teachers can improve the model and the concept in teaching in order to meet the development demands of the school. It avoids machine-made teaching contents and teaching methods, at the same time, realizes diversified teaching in colleges. At the meantime, it avails the existence and development of different teaching ideas. Teachers teach according to different phenomenon. What's more, they make different students achieve full development on the original basis.

\section{A. Establish Scientific Teaching System Structure}

Sports clubs in universities are products of sports teaching. It develops in many aspects and the development is systematic. According to investigation and survey, we can summarize the system structure of college development as the following types, including the type of teaching club, the type of promotion club and the type of competitive race club.

\section{1) The type of teaching club}

Teaching club takes teaching as the basis, in order to strengthen the sports skills and ability of students and improve their physical quality through collective teaching. Teaching contents include theoretical knowledge, athletic ability of special events and the enhancement of awareness of students in workout. Lecturers and teaching assistants are provided, in order to better improve educational and teaching quality. Teaching club does the basic and the most important work of sports club in teaching, because the learning contents at this stage determine whether students can grasp solid basic technique. At the meantime, it is the primary and important work of teaching. This stage resembles the foundation of buildings. We can only construct buildings on the solid foundation. So to speak, the work at this stage has very important effect on the improvement of teaching quality.

\section{2) The type of promotion club}

Classroom teaching is far from adequate to learn and grasp sports skills. It is because the class hour is limited and teachers only teach and train basic technique, in order to make the mass, especially students grasp sports skills. In order to truly improve technique, students must carry out intensive training after class. Three to five times of specialized training are provided in every week, in order to improve the skills of students in special events, at the meantime strengthen the ability of them in technique and tactics and their proficiency in technique. If students fail to solidly grasp technique, they must carry out intensive training, in order to further improve their technique. At this stage, the teaching aims at further strengthening and developing students who have grasp basic technique at the meantime promoting the further development and improvement of technique.

\section{3) The type of competitive race club}

Solid basic training resembles depositing money in banks and competition resembles withdrawing money from banks. Competitive race is one of the important means to check skills of students. Competitive race club is established to develop the competition ability of students. Students can find deficiencies of their own through competition with other competitors. They can continuously improve competitive ability in promotion club. Competitive ability recycles in training and competition. Competitive race club effectively makes up for deficiencies of students in teaching club and promotion club. More importantly, the organization of competitive race club improves the ability of students in organizing competition and their ability in referee execution. Obviously, the appearance of competitive race club is comprehensive on the basis of teaching club and promotion club.

\section{B. Establish Scientific Evaluation System}

Teaching evaluation refers to the activity that judges the value of teaching process and results according to teaching objectives and serves teaching decision. It's the process that judges the realistic or potential value of teaching activities. In traditional teaching evaluation, the teaching ability of teachers and the learning situation of students are judged according to the teaching performance. With the appearance of new courses, the evaluation method changes from single evaluation method to diversified evaluation method. In club teaching, under the guidance of teachers, students independently set learning objectives and learning progress, in order to fulfill learning contents and learning tasks. Compared with the previous teaching evaluation method, the teaching evaluation method is more reasonable and sounder. It changes the single teaching method that consists of the teaching of teachers and the learning of students. At the meantime, it changes the single evaluation method. Furthermore, the teaching evaluation emphasizes the dominant position of students. It gives play to the autonomy of students and effectively points out problems in teaching. Teachers and students can find problems of their own through teaching evaluation. Teachers can ceaselessly improve their teaching ways and methods in the future. At the same time, students improve their sport technique in spare time after finding their deficiencies.

\section{Stimulate Enthusiasm of Teachers in Teaching and Enthusiasm of Students in learning}

If college education wants to achieve better effects, there are two key factors, one is teacher and the other is student. 
Good teaching effects can be achieved if teachers are enthusiastic about teaching students and students take the initiative in learning. Club teaching fully simulates enthusiasm of both students and teachers. In club teaching, students have many alternative events to choose. They will take the initiative to participate in the process of choosing their favorite events.

The implementation of club teaching makes the construction of teaching staff have new changes. Club teaching changes the traditional teaching model. In traditional teaching, the class is fixed and the number of students is also fixed. It raises new requirements for teachers. In order to adapt to new teaching model, teachers must learn continuously at the same time change traditional ideas. Besides, they can improve ability through learning.

\section{CONCLUSION}

At the present stage, majority of the sports teaching in universities follows the traditional teaching models and methods. In traditional teaching, the teaching thought is fixed and backward, so that it cannot meet the development demands of students in the new era. Sports club in universities has affluent contents. The management is sound. Students are enthusiastic. Therefore, it meets the development requirements of university at the present stage.

Universities are suggested to establish scientific teaching structure through teaching club, promotion club as well as competitive race club. They can take the initiative to construct sports clubs and implement sports club teaching. At the meantime, universities can improve the club-type of teaching evaluation system, in order to meet the requirements of teaching and development of them.

\section{REFERENCES}

[1] Liu Zhimin. Analysis on the Concept of Club in Physical Education of Universities [J], Sports Culture Guide, 2004 (8): 56-57

[2] Yang Wenying, Pang Guozhong. Research on Sports Club of Chinese Universities from the Perspective of Systems Engineering [J], Social Sciences Journal of University in Shanxi, 2012(12): 109-112

[3] Jiang Degang, Hao Deyong. Mission on Cultural Construction of Modern Curriculum [J], Journal of Higher Education, 2001, 22(6): 86-88

[4] International Commission on Educational Development of UNESCO, Learn How to Exist: Today and Tomorrow of Education World [M], Beijing: Education Science Press, 1996: 98

[5] Chen Xi. Organization and Management of College Sports in the Changing Period [J], China Sport Science, 2002, 22(4): 2-3. 